\title{
CONTEMPORARY SCHOLARLY UNDERSTANDINGS OF QUR'ANIC COHERENCE
}

\author{
Andrew Rippin*
}

\begin{abstract}
A good deal of recent scholarship on the Qur'an has focused on the structure of the surahs, arguing that there is a coherence to be seen therein. That sense of coherence is found in different bases: contextual flow, theme and content, language and style, and structure. The question is asked as to why this has become such a dominant mode of analysis. Trends in biblical studies and general literary theory are considered as prompting this greater attentions to the aesthetics of texts. It is suggested that this approach to the Qur'an then reflects contemporary ideas and that it is important not to view such approaches to coherence as "proving" the point: there are other possible approaches to reading the Qur'an.
\end{abstract}

Keywords: Qur'ān, structure, coherence, structure, literary theory, Angelika Neuwirth, Michel Cuypers

When scholars read the Qur'ān they are confronted with a text that requires the adoption of a series of assumptions in the reading process in order to derive meaning from the written words. So, when we ask questions about the methodologies that lie behind how the Qur'ān should be studied, how it should be understood and how it should be interpreted, as is required when "rethinking" the Qur'ān, we must initially address carefully the question of how we go about reading the Qur'ān in the first place. Some of the assumptions behind our methodologies related to this process of reading are "common sense" ones; they are features of the reading of any text. For example, the nature of the language employed must be commonly assumed. Virtually all scholars agree that the text of the Qur'àn is written in

University of Victoria, Canada. E-mail: arippin@uvic.ca

(C) 2013 Al-Bayān Journal.

Published by Department of al-Qur'an and al-Hadith, Academy of Islamic Studies,

University of Malaya, 50603 Kuala Lumpur - Malaysia. 
Arabic and that we can use the resources of the Arabic lexicographical and grammatical traditions to understand the text, as long as that is done with an appropriate critical perspective. The point here is that we do not consider that the text might be written in some sort of code that requires a key in order to decode it; we assume the text is a meaningful act of linguistic communication. Other assumptions are subject to more debate among scholars, especially those related to the historical context into which the text needs to be put in order to understand it. The main lines of this debate as it manifests itself today tend towards considering the extent to which broadly based Jewish and Christian scriptural traditions may be seen as important sources of information for understanding the Qur'ann as compared to specific Arabian traditions that may have local Jewish and Christian elements mixed in with them. Much of this becomes framed within another discussion that concerns the extent to which history, especially what is embedded in the Sira, should be used to contextualize the text of the Qur'ān. The separation between Meccan and Medinan sürahs is the obvious and fundamental place where this issue arises: are there independent criteria that allow one to read the Qur'ann within that sense of historical and religious development? Such discussions are fundamental parts of scholarly analysis.

There is a third area that has become a particular focus of attention in recent years which revolves around theories about the units of literary structure in the text. To put this most plainly, the issue is usually framed as being about whether one should read each surrah as a whole (usually with the possibility of some Medinan verses being found in Meccan sürahs) or read the Qur'ān as a series of shorter pieces.

My interest in discussing this topic was aroused by an observation made by Carl Ernst in his recently published book, How to Read the Qur'an, in which he states: "... appreciation of the internal structure and organization of the Qur'ān is extremely helpful for grasping its overall message, and it offers ways to comprehend the relation of one passage to another. Within the chronological framework, the primary unit of analysis is the sürah, which needs to be understood as a literary whole rather than a random assortment of unrelated 
verses." This assertion concerning the "primary unit of analysis" being a surah is, in Ernst's estimation, the dominant trend in scholarship today. Others have also remarked on this, the discussion probably starting with Mustansir Mir in an essay published in $1993 .{ }^{2}$ But this basic point raises a question which it seems to me has not been fully discussed. Ernst is certainly right that several important trends in modern Qur'anic research do pay particular attention to the sürah as the basic unit of analysis. The truth of this observation particularly struck me at a 2012 conference on the Qur'àn held in Chicago at which a significant number of papers seemed to involve an argument for the unity of extended literary units in the text; I also noticed this trend in a number of papers delivered at the American Academy of Religion meeting also held in Chicago in 2012. I wondered then as I continue to wonder - why it is that the notion of examining the Qur'ān in segments of substantial length - often entire sürahs - has become so dominant in academic circles. How do we account for this dominance in our discipline?

The goal of this paper, then, is to argue that, as academic readers of the Qur'àn, we need to be conscious of the situated-ness of our own readings within our own scholarly perspectives. I will suggest that the notion of the unity of the surah (and implicitly often, the Qur'ān itself) in the way it is employed as a reading strategy is, at least in part, a reaction to contemporary literary trends outside the study of the Qur'ān. This assumption about the literary structures of the Qur'ān, which does appear to have become a dominant mode of scholarly analysis at this particular point in history, is also marked by a tendency to try to prove a singular perspective - and to see any challenges to that as evidence of the "disarray" or "crisis" or "incoherence" of our discipline. This perspective not only constrains explorations of the text of the Qur'ān but also avoids directly dealing

Carl W. Ernst, How to read the Qur'an: a new guide, with select translations (Edinburgh: Edinburgh University Press, 2011), 12.

Mustansir Mir, "The sūrah as a unity: a twentieth century development in Qur'ān exegesis," in Approaches to the Qur'an, ed. G.R. Hawting \& Abdul-Kader A. Shareef (London: Routledge, 1993) 211-24. Salwa El-Awa, Textual relations in the Qur'an: relevance, coherence and structure (London: New York: Routledge, 2006) chapter 1, has a good overview of classical and scholarly approaches to the structure of the Qur'ān. Also see Nevin Reda, "Holistic approaches to the Qur'ān: a historical background," Religion Compass 4 (2010), 1-12. 
with some of the more challenging aspects of the Qur'àn as a text. As a conclusion I will suggest that other ways of understanding the Qur'ān with a focus on the analysis of the reader's experience (rather than entertaining theoretical literary structures) may provide an alternative productive solution to what sometimes seems to be the dilemma of how to read the Qur'àn from an academic perspective.

\section{The literary unity of extended passages}

Discussions of the literary unity of extended passages of the Qur'anic text often position an affirmation of the strategy in opposition to the "atomistic approach" of medieval exegesis and also in opposition to the philological approach of some contemporary scholarship that focuses on single words or phrases. However, this is a description that captures neither the reading experience of the classical exegetes nor the approach of the philologists; rather, it is a rhetorical move by contemporary writers that serves to justify discarding the legacy of earlier times. For the medieval exegetes, while the text is divided up into short segments for attention, it is never read in a manner that is innocent of what is found in the text elsewhere. The exegetes held to an implicit unity of structure and content, even if the form of their writings in the genre of tafsir disguised that in its phrase-byphrase approach. Certainly the exegetes did not often look for latent connections between verses and some writers even denied that they were necessarily there. But a consciousness of the unity of the canon underlies much of the classical exegetical technique which looks for parallels and similarities throughout the text in order to understand it; it also underpins the essentially linear approach of reading which is perhaps where the main difference lies when compared to some modern theories on the literary unity of extended segments, as we shall see.

The unity of extended segments is also often seen to be in tension with a fully historical and philological reading which sees each portion of the text driven by changing historical contexts, as reflected in classical Muslim thought with the idea of asbāb al-nuzūl, and, in scholarship, in the way it has adopted and adapted this classical Muslim perspective. The demands of history suggest the ability to define the segments of the Qur'ān into smaller and smaller 
pieces. However, this obscures the fundamental issue because, when we speak of "unity", the concern is really about how large a segment is to be considered the basic unit that will drive one's interpretation of the text. Such extended literary units may still be considered to be embedded in a historical context.

An underlying point in notions of the unity of extended passages concerns the flow of the text. It is important to remember that decisions about the flow of a text make a significant difference to the process of understanding the text. On that, I think we can all agree. There are some classic examples of where this notion of textual context - which is then driven by a notion of the unity of a segment of the text - can be seen to affect the meaning of the text. One obvious instance would be in the story of the intended sacrifice of Abraham's son. As has often been pointed out, reading sürah al-Ṣäffät (Q 37) in a linear fashion means that verse 101, So We announced to him the good news of a prudent boy, must refer to Ishmael (and thus he is the intended sacrificial victim) since the subsequent verse 112 states, And We announced to him the good news of Isaac, a prophet from among the righteous. While it is possible to hold that unity of the sürah does not demand linear narrative progression - and several contemporary theories explicitly deny this linearity - such a simple example does show that the issue of segmentation of the text is a critical one for any reader. The unity of sürah al-Säffät is essential to a reading which sees these two references as necessarily different sons of Abraham.

As a theory about the text of the Qur'ān, the idea of unity of extended segments of the text has especially been put forth through attempts to put it on rigorous grounds (we might say "scientific" grounds). Such theories lead directly to reading strategies, but what we see as privileged in these theories is the desire to prove or at least to demonstrate a sense of the literary unity of an extended segment. This is important: the argument is not being made on the basis of the reader's experience - it is not the "totality of effect or impression" 3 that is the referent of unity of the extended segment in

This is the language of Edgar Allan Poe in speaking about the composition of poetry in his "The Poetic Principle" written in 1850. The text of this essay is available at <http://classiclit.about.com/library/bl-etexts/eapoe/bl-eapoe-poetic.htm/> Accessed 
these discussions; such a sense of "unity" or "totality" would reside in the reader and demands a conscious decision on the part of the reader to sit down and read a section of text as a whole. Rather, the text is being approached from the angle of its literary structure and, implicitly, it is being suggested that we must read the segments of the text as extended and even intentionally constructed that way from the author's perspective.

Such arguments about theories of the unity of extended segments of text proceed on a number of bases which need to be distinguished. They can also be traced to a wide variety of scholars which suggests that this is a trend that is more widespread than simply something that has occurred as the result of the influence of one particular approach which has come to dominate. The approaches I will describe do not necessarily exist in isolated form; these categories should perhaps be viewed as summaries of general trends that can manifest themselves in a variety of ways.

In the first approach, the connectedness of verses and süras has been an observation within the medieval Muslim exegetical approach, often linked to the idea that there is wisdom in the way in which the text is organized. Such is often termed 'ilm al-munāsabāt and was made prominent by al-Suyūṭi and al-Zarkashī. ${ }^{4}$

Second, that sürahs are united by theme and content has been argued by many people, including Sayyid Quṭ with his idea of a "central axis", mihwär, that holds each literary unit together. This approach is also inherent in many other approaches such as with Iṣlāhì and his emphasis on the idea of 'amūd in his development of

5 October 2013.

For an examination of the analysis of sürah 77 by al-Iskāfî, see Andras Hamori, "Did medieval readers make sense of form?: Notes on a passage of al-Iskāfî," in In quest of an Islamic humanism: Arabic and Islamic studies in memory of Mohamed al-Nowaihi, ed. A. H. Green (Cairo: AUC Press, 1984), 39-47. One point that emerges from this analysis is that classical readings are not always totally linear and that there was some awareness of literary structures at a sophisticated level. Mustansir Mir, in his paper presented at the "Rethinking the Qur'an" conference, provided an outline of three approaches to the question of nazm among exegetes that is helpful in thinking about the various aspects of "connectedness" in exegetical thought: his three categories of context, coherence and continuity adds additional subtlety to this aspect of my analysis here. 
the notion of nazm. Such approaches work primarily on the basis of content first and then determining the linkages between sections of content.

Third, that surahs are united by language and style is an approach that has become a central element in several theories but it is particularly notable as an isolated theory in the recent work of Behnam Sadeghi in undertaking what he calls a "stylometric" analysis of the Qur'ann. ${ }^{5}$ Such an approach avoids all contact with the content and structure of the text but focuses solely on the stylistic character of the language. Sadeghi's approach looks at the most common morphemes in the text (mainly grammatical markers) and traces their repetition and patterning in extended passages. He sees divergences in frequency in the usage of different morphemes among different segments. He then argues that dividing large segments into half reveals that the frequency of morphemes is similar within both halves of an extended passage. Thus, he concludes, those two halfsegments are similar in style and clearly belong together.

Fourth, that surahs are united by an underlying structure is undoubtedly the most popular approach today. Those underlying structures take on a variety of forms including sermonic and liturgical - as spoken of especially in the work of Angelika Neuwirth ${ }^{6}$ - and rhetorical, as seen in the work of Michel Cuypers. ${ }^{7}$ Such structures

5 Behnam Sadeghi, “The chronology of the Qur'ān: a stylometric research program," Arabica 58 (2011) 210-99. For an approach that concentrates on rhyme and word usage, see Shawkat Toorawa, "Sürah Maryam (Q. 19): lexicon, lexical echoes, English translation," Journal of Qur'anic studies 13 (2011), 25-78.

$6 \quad$ Neuwirth states, "[M] any sürahs are structured after a sophisticated pattern and employ effective rhetorical strategies"; see her "Meccan texts, Medinan additions? Politics and the re-reading of liturgical communications" in Words, texts and concepts cruising the Mediterranean sea, ed. R. Arnzen, J. Thielmann (Leuven: Peeters, 2004) 72. For her, the conflict between the idea of a non-contingent scripture and history is resolved by a determination of (historically bound) literary forms that are deemed to convey meaning. Also see her "Reclaiming Babylon: the multiple languages of the Qur'ān," in Islamic thought in the Middle Ages: studies in text, transmission and translation, in honour of Hans Daiber, ed. Anna Akasoy, Wim Raven (Leiden: Brill, 2008) 565-91. The issue, often raised by Neuwirth concerning the "pre-canonical" or "pre-redactional" status of the text, is placed within the context of the history of the life of Muhammad and thus allows not only literary observations but historical ones as well.

Cuypers's studies of the Qur'ān (as well as in his studies on other segments of the text) is situated within the theoretical structure enunciated by Roland Meynetknown as 
can also involve observations on theme and content as well but, most importantly, these theories assert that the text must use such forms regardless of content because that form is what was required for the message of the Qur'ān. ${ }^{8}$

Many scholars have looked at the structural features of the sürahs ${ }^{9}$ and each has used his or her own theoretical structures and vocabulary for the delimitation of Qur'anic segments and the literary character of the overall text. The goal of all of these efforts has been to reject what is understood to be the claim of some other scholars that the Qur'ān is a jumble of texts with forced rhyme, that was composed with little overall conception during an extended period of time and then put together by editors who had little understanding of the original intention of the text. Rather, the argument is that there is a unity that can definitely be perceived in each extended segment and it is a unity that can be uncovered.

What marks these approaches is the certainty with which their practitioners argue their theories: the implicit claim is made that an analysis produces an "objective" result because of the uniformity of structuring within the overall text of the Qur'àn (or, perhaps, within chronological periods). Gabriel Reynolds in a review of Michel Cuypers' work on Q 5 suggests that Cuypers ends up arguing "that

\footnotetext{
"Semitic rhetoric"; see Michel Cuypers, "Semitic rhetoric as a key to the question of the nazm of the Qur'anic text," Journal of Qur'anic Studies 13/1 (2011), 1-24. Cuypers' work has the goal of uncovering composition coherence and does so by attempting to demonstrate that the Qur'ān is an exemplum of Semitic rhetoric and that the rhetorical forms found within the Bible can help in understanding Muslim scripture. Gabriel Reynolds in a review of Cuypers' work on sürah 5 suggests that Cuypers ends up arguing "that the Qur'ān is organized with a breathtaking mathematical precision" (Der Islam 88 [2012] 430). Rachel Friedman comments regarding Neuwirth that she emphasizes that "the Qur'ān does indeed work based on an internal logic that careful readers can discern (although, notably, none did notice this pattern of structures before these recent structuralists)." ("Interrogating structural interpretation of the Qur'ān," Der Islam 87 [2012] 139).

9 Other works include Pierre Crapon de Caprona, Le Coran, aux sources de la parole oraculaire: structures rythmiques des sourates mecquoises (Paris: Publications Orientalistes de France, 1981); Neal Robinson, Discovering the Qur'ân: a contemporary approach to a veiled text (London: SCM Press, 1996); Mathias Zahniser, "Major transitions and thematic borders in two long sürahs: al-Baqarah and al-Nisă," Literary structures of religious meaning in the Qur'ān, ed. Issa J. Boullata (Richmond: Curzon, 2000), 2655.
} 
the Qur'ān is organized with a breathtaking mathematical precision". Rachel Friedman comments that Angelika Neuwirth emphasizes that "the Qur'ān does indeed work based on an internal logic that careful readers can discern (although, notably, none did notice this pattern of structures before these recent structuralists)." Fundamentally, these observations about unity of extended passages from people such as Cuypers and Neuwirth are not always convincing, however. It is frequently easy to document that the structures that are proposed by one author are different from those proposed by another reader of the very same text. We see, thus, that these structures are imposed by the reader: they do not naturally "emerge" from the text. Such structures are, in fact, readings of the text that exist as scholarly objects. Such readings also, in my view, miss (or at least gloss over) an important part of any text: disruptions. Sections which disturb an easy reading, which do not fit, which break the language or the theme or the structure tend to be downplayed (or even denied) rather than highlighted. Yet such disruptions may also convey meaning through the very act of disruption; they may also act as disruptions to shake the reader to attention.

\section{Why an emphasis on the unity of extended passages?}

My point here, however, is not to critique these approaches that emphasize the unity of extended passages. It is the intellectual development of this trend in approaching the Qur'ān that attracts my attention. Of course, the idea of approaching surahs as whole units is not entirely new in scholarship. In the $19^{\text {th }}$ century Theodor Nöldeke ${ }^{10}$ approached sürahs in this way, except where he felt there were definite intrusions of Medinan portions into Mecca sürahs in the text, following Muslim tradition. But the work of some subsequent scholars ${ }^{11}$ emphasized the discontinuities in the text and thus the thought arose that segmentation into shorter units provided the best model by which to understand the meaning (and the historical context) of the text. These two views have co-existed with very little

$10 \quad$ Theodor Nöldeke, F. Schwally, G. Bergsträsser, O. Pretzl, Geschichte des Qorans. 3 vols (Leipzig: Dieterich'sche Verlagsbuchhandlung, 1909-38).

11 Prime examples of this are Jakob Barth "Studien zur Kritik und Exegese des Qorāns," Der Islam 6 (1915) 113-48, and Richard Bell, especially in his The Qur'än, translated with a critical rearrangement of the sürahs. 2 vols (Edinburgh: T \& T. Clark, 1937-9). 
consideration of the basic issue until recently. So the question must be, what has recently motivated the discipline to emphasize larger literary units as the basis for analysis?

It does seem that the idea as expressed in unity of theme in sürahs as found in early $20^{\text {th }}$ century Muslim exegetical works of Farāhī and Islāhị has certainly drawn the attention of scholars to the basic idea. In Mustansir Mir's analysis of the rise of Muslim theories on the unity of surahs, ${ }^{12}$ he holds out the possibility that such ideas themselves may stem from a reaction to long-standing Western accusations of the disjointed character of the Qur'ān. Might then this contemporary scholarly acceptance of unity of extended segments of the text be viewed as an apologetic response, stimulated by the Muslim turn? ${ }^{13}$ This is an explanation that cannot be discounted. Mir's explanation of the Muslim interest in this approach of emphasizing unity as a way of discarding the "baggage" of earlier times and re-reading the Qur'ān to assert its relevance to the modern day is certainly a compelling explanation for the phenomenon in devotional settings; it is not convincing, however, when trying to account for the academic focus.

In order to understand this emphasis on analysis of extended segments of the text in scholarly works I believe it is necessary to look outside the field of Islamic studies. In biblical studies the tendency to break the text of the Bible into small pieces developed out of a need to understand the composition of the text. The failure to find elements that suggested a single author for individual books of the Bible drove scholars to devise theories - source criticism and form criticism especially - that would allow texts found in single books of the Bible to be intelligible as conglomerations of pieces,

Mir, "The sūra as a unity”, 211-24.

Such an apologetic trend is not unique to Qur'anic studies; it may also be observed in other areas of religious studies. See, for example, Emily T. Hudson, Disorienting Dharma: Ethics and the aesthetics of suffering in the Mahābhārata (New York: Oxford University Press, 2013), 20-1, where she speaks (approvingly) of a "hermeneutics of respect" that "seeks to listen to rather than disembowel the text; it assumes that what is most interesting about the Mahäbhärata is what the great epic has to say for and about itself, rather than what it has to say about its pre-history or its future. Indeed, scholars today are beginning to see that many of the literary features that their early twentiethcentury predecessors held in disdain - its size, its riddles, its open-endedness, even its dark worldview - are integral to the epic's distinctive literary genius." 
by placing those smaller pieces in their historical context of origin. However, in response to such approaches, powerful new theories arose in the $20^{\text {th }}$ century. Those theories started from the fact of the existence of a biblical canon that, it was argued, "must presumably have been assembled by someone" 14 who had the goal of presenting an intelligible text with some notion of a genre behind it as the end result. That is, in biblical studies, scholars such as Brevard Childs and James Sanders, working in the 1970s, argued for "canonical criticism" that saw meaning emerge out of the individual books of the Bible as they had been assembled in the overall book. ${ }^{15}$

This development in biblical studies did not, in itself, exist or develop in a vacuum; here, too, we need to look to broader trends in literary criticism in order to understand the emergence of these ideas. This turn to paying attention to the unity of extended textual segments also reflects trends in literary criticism in a more general sense. There are substantial parallels between biblical "canonical criticism" and what is known as "new criticism" in literary circles: the focus on the text itself and the close reading of it, rejection of the original author's intention, and disinterest in the historical context of the text. ${ }^{16}$ While "new criticism" itself has been subjected to extensive critique and no longer holds a prominent place in academic literature circles, in modified forms it continues to be a powerful theory especially among those who wish to see a return to an appreciation of aesthetic values of literature.

14 John Barton, Reading the Old Testament: Method in Biblical Studies(London: Darton, Longman and Todd, 1984), 43.

15 Neuwirth acknowledges, e.g., in "Vom Rezitationstext über die Liturgie zum Kanon: zu Entstehung und Wiederauflösung der Surenkomposition imVerlauf der Entwicklung eines islamischen Kultus," The Qur'ān as text, ed. Stefan Wild (Leiden: E.J. Brill, 1996), 69-105, her own indebtedness to Childs and Sanders. In more recent work, however, she has placed emphasis on Jan Assmann and his theories of canon. Regardless, given the widespread acceptance of sürah unity on various theoretical bases, the current situation cannot be seen just as a result of Neuwirth introduction of these ideas into Qur'anic studies. That such studies emerged because, in Childs' case certainly, of a growing concern that critical methods were "unsatisfactory theologically" (Barton, Reading the Old Testament, 79) and that bridging the gap between the past and the present when it comes to reading the Bible is essential to the theological task, needs to be recognized when thinking about this as a method in relationship to the Qur'ān.

16 See Barton, Reading the Old Testament, chapter 10. 
I do not wish to argue for a simplistic sense of influence or imposition of theories from outside in scholarly dealings with the Qur'ān. Rather, it is the general sense of the changing mood of academic interest in, and approaches to, texts that seems to be most important. These observations lead to several questions. Is this attention to larger compositional units in the Qur'ān part of a general academic response reflective of concerns manifested in many quarters in the early $21^{\text {st }}$ century about the "destructiveness" of the search for sources and the layers of composition? Is this attention to large units reflective of a drive seen in some parts of literature departments to move away from theory and to return to the study of "literature" and aesthetic qualities and so forth, often viewed as a rather reactionary stance and a move back to a reformulated "new criticism"? Is this a rejection of the idea of the political nature of literature in which the situated-ness of the text is primary and is it a return to an emphasis on a text's aesthetics and composition, a safer view of scripture in this highly politicized world in which we live? ${ }^{\text {? }}$

I do not believe that there are simple answers to these questions I have just posed. However, the main point I would wish to make is that as academic readers of the Qur'an we need to be conscious of the situated-ness of our own readings. The tendency to wish to prove a singular perspective - and to see any challenges to that as evidence of "disarray" or "crisis" or "incoherence" of our discipline - is certain of failure because of the shifting nature of academic perspectives. I would not deny that these structural studies are valid readings that bring out meaning for the reader who wishes to adopt them. But, as scholars, we must guard against claiming a monopoly on meaning production through one particular approach. It is important to underscore the basic point that there are particular contemporary values that are associated with coherence and unity and that our

17 For some provocative reflections upon such questions in the context of biblical studies, see Yvonne Sherwood, Biblical Blaspheming: Trials of the sacred for a secular age (Cambridge: Cambridge University Press, 2012), esp. 83-89; Sherwood points to the complexities of scholarship in our secular context when it comes to dealing with a text such as the Bible which is, through the force of criticism, maintained as a "sacred" object; the role of literary criticism is reacting to what its practitioners saw as the "desacralising disdain" of redaction criticism is also what we see in Qur'anic studies. But this reflects a complex process of shifting sense of the tensions between the sacred and the secular in contemporary society. 
scholarly world devoted to the Qur'ān is simply reflecting them.

And there are other approaches that avoid some of the subjectivity of the ideas related to the extended segments of texts and, at the same time, do not result in the reduction of the text into short segments that imply that there is no literary unity. It is important to remember the point with which I started: one must decide upon a reading strategy as the first step in understanding and thus teaching and studying - the Qur'ān.

\section{Towards rethinking the Qur'ān}

A dilemma has been set up in what has preceded: reading the Qur'ān demands that one adopt a certain range of reading strategies that pay attention to literary units in order to define the extent of the context within which understanding will take place. An approach that looks at large literary units, as I have argued above, while making claims to objectivity, remains as subjective as any other approach that looks at smaller units of text and is reflective of other intellectual trends of current times.

However, the idea of the unity of the text can be employed as a conscious presupposition as a way to approach the text such that the text is framed by the reader's experience, whether that reader is conceived as being from the $7^{\text {th }}$ century or the $21^{\text {st }}$ century. This would often be called a synchronic approach - and in some discussion ${ }^{18}$ this is accused of entailing theological assumptions; it is argued that, when viewed in historical terms, a synchronic approach assumes the existence of a canonical text that is only in the possession of the later Muslim community and not in the moment of the stages of Muhammad's life. Semantic readings, such as those we associate with Izutsu, and discourse analyses that focus on the language of the Qur'àn are examples of approaches in which the reader is consciously placed in front of the canonical text as a whole; the emphasis then becomes on how the text is experienced by the reader. There is no argument being made about literary units; the strategy is simply adopted as a "fact". Can such an approach provide

18 See the way Ernst phrases this, How to Read the Qur'ān, 10, as a "post-canonical perspective" in his dismissal of thematic approaches to the analysis of the Qur'ān. 
a model for analysis? It is certainly an avenue worth exploring.

A scholarly approach that would address some of these questions is "reader response" theory or "reception history"; that this is a direction that Qur'anic studies could and should go in I have pointed out in some of my earlier writings. ${ }^{19}$ Such a scholarly perspective avoids some of the intrinsic problems outlined above. The fundamental outlook is a common one. Meaning is not simply "present" in any text ready to be extracted; rather, meaning is created anew through the act of reading by each individual. That does not make meaning arbitrary. The act of creating meaning occurs in a social space that shares certain common understandings: such is the basis by which we successfully communicate to one another, because we accept the conventions of discourse. My own particular interest then has become the historical record of how Muslims have read the Qur'ān, as embodied in works of tafsìr.

In terms of a contemporary reading of the Qur'ān, as a method of "rethinking" the Qur'ān, such a perspective would encourage attention to, and reflection upon, the "social space" in which understanding takes place. It requires an analysis of the presuppositions not only within the act of reading itself as I have raised here, but also from the perspective of the values which are to be elicited from the Qur'ān and the need to be explicit about them. That then creates the "social space" of communication. There will, of course, be different understandings produced as a result. Some will find their common social space in the context of the modern secular university, others within a seminary context. These are, I continue to think, approaches that need to be explored further in the study of the Qur'ān.

19 For example, Andrew Rippin “The Qur'ān as literature: perils, pitfalls and prospects," British Society for Middle Eastern Studies Bulletin 10 (1983), 38-47. 